\title{
A REGRESSÃO DA AUDIÇÃO E A BARBÁRIE: AS (IM) POSSIBILIDADES DE TRANSCENDÊNCIA DA MÚSICA ESTANDARDIZADA
}

\author{
Paola Regina Carloni \\ Faculdade Araguaia/Faculdade Alfredo Nasser, Goiânia, Goiás, Brasil
}

\begin{abstract}
Resumo: A arte é possibilidade de transcendência e humanização. Ao ser retirada do seu caráter reflexivo e lançada na lógica da indústria cultural, a arte se torna um elemento a ser consumido e expressão de barbárie, pois a alienação impede a humanização. A regressão da audição na música e sua estandardização são elementos que levam à alienação, impossibilitando a transcendência. Este trabalho compreende aspectos da música na atualidade, que impede o sujeito de viver plenamente a humanização e converte essa expressão da arte em barbárie. As análises neste artigo são feitas com bases em uma pesquisa bibliográfica fundamentada nos conceitos da Teoria Crítica da Escola de Frankfurt.

Palavras-Chave: Barbárie. Estandardização. Música. Transcendência
\end{abstract}

INTRODUÇÃO

A arte contém em si a possibilidade de transcendência, pois, ao mesmo tempo em que retrata a realidade, consegue abstrair-se dela, permitindo a denúncia e a crítica, ao apontar as contradições e as aflições humanas. Nesse sentido, ao ser possibilidade de reflexão e crítica, a arte seria também possibilidade de combate à barbárie, fator fundamental para o processo de humanização. "Eu começaria dizendo algo terrivelmente simples: que a tentativa de superar a barbárie é decisiva para a sobrevivência da humanidade" (ADORNO, 2006, p.156). 
No entanto, na sociedade capitalista, pautada pela indústria cultural, a arte como transcendência vai sendo impossibilitada à medida que se transforma em mercadoria, tornando-se entretenimento reificado e impossibilidade de humanização, recaindo em barbárie.

Neste artigo, compreende-se a música como arte. Assim, ela poderia transcender a realidade. No entanto, na indústria cultural, ela se torna um bem a ser consumido, o que impede sua composição como arte, mudando as próprias relações sociais que se tornam, no capitalismo, alienadas. "A modificação da função da música atinge os próprios fundamentos da relação entre arte e sociedade" (ADORNO, 1983, p.173).

Para Marcuse (1977), assim como para Adorno (1983), a arte precisa transcender a realidade. Segundo Marcuse (1977), uma obra é considerada autêntica se ela for revolucionária, ao contestar e transcender a realidade. Para esse autor, ao se alienar da realidade humana, a arte comunica verdades incomunicáveis e não reconcilia o sujeito consigo mesmo ou com seu contexto social, mas permite uma autorreflexão sem aplacar a tensão entre sujeito e objeto ou entre universal e particular. Conforme ele, "o final feliz é o contrário de arte" (MARCUSE, 1977, p. 55).

Marcuse (1977) defende que a arte só transcende a realidade e, portanto, se torna obra de arte autêntica se for revolucionária, o que poderia levar ao combate à barbárie. Nessa perspectiva, a obra precisa ir além do contexto apresentado, mas possibilitar uma expressão das contradições do homem, seja consigo mesmo, seja com o contexto social, que transcenda a realidade factual.

Assim, no primeiro item deste artigo, se discute a arte, trazendo autores como Marcuse (1977), Adorno (2006; 2011; 2015) e Horkheimer e Adorno (1985). Nele, abordam-se a (im)possibilidade de transcendência da arte no capitalismo e ainda a função da arte como ferramenta revolucionaria e crítica, que poderia atuar contra a barbárie. Em seguida, compreende-se a arte no contexto da indústria cultural.

Para finalizar, no segundo item, dialoga-se com os estudos sobre música popular de Adorno e Simpson (1994) e sobre a regressão da audição em Adorno (1983). Questionam-se, então, quais as possibilidades de criação e transcendência diante da realidade objetivada e estandardizada, conceito que o próprio autor desenvolve. Na estandardização, os hits musicais, que se tornam um sucesso, seguem uma fórmula pré-programada e tudo o que foge a esse padrão é excluído ou tido como de mau gosto. Assim, a música deixa de ser arte e se torna um produto de entretenimento, que precisa seguir determinados padrões para ser vendida, resultando em barbárie. 


\section{1 - ARTE E INDÚSTRIA CULTURAL: A IMPOSSIBILIDADE DE TRANSCENDÊNCIA COMO} BARBÁRIE

Para Adorno (2006), é fundamental colocar o tema da barbárie como central nas discussões intelectuais, a começar pela própria educação: "a tese que gostaria de discutir é a de que desbarbarizar tornou-se a questão mais urgente da educação hoje em dia" (ADORNO, 2006, p. 155). O autor explica que a barbárie é uma expressão extrema da violência, ela existe em toda parte e sua pior expressão é a regressão à violência física. No entanto, há vários atos que aparentemente não são violentos, mas também são bárbaros. Situações muitas vezes justificadas pela lógica desigual do capitalismo são atos de barbárie, como privar os seres humanos de experimentar as condições de progresso e evolução alcançadas pela civilização, ou seja, se humanizar no sentido mais profundo do termo. "[...] entendo por barbárie algo muito simples, ou seja, que, estando na civilização do mais alto desenvolvimento tecnológico, as pessoas se encontrem atrasadas de um modo peculiarmente disforme em relação a sua própria civilização" (ADORNO, 2006, p.155). Esse atraso se dá por não terem experimentado a formação em sua expressão mais ampla, cultural e intelectualmente,"mas também por se encontrarem tomadas por uma agressividade primitiva, um ódio primitivo ou, na terminologia culta, um impulso de destruição, que contribui para aumentar ainda mais o perigo de que toda esta civilização venha a explodir" (ADORNO, 2006, p.155).

A arte, como elemento cultural e social, seria, portanto, elemento fundamental no processo de humanização. Privar os indivíduos de experimentar a arte é barbárie. Entretanto, diante do cenário que leva a Auschwitz, Adorno (2011) se questiona sobre o estudo dos elementos da composição musical como algo bárbaro, visto que outras questões poderiam se apresentar como mais urgentes para a reflexão, dado o estado de horror que mergulhou a humanidade no século XX. Apesar desse questionamento sobre a relevância do estudo da música diante do atual cenário de barbárie, o autor justifica a necessidade de se estudar arte, pois o entendimento da própria reificação e da alienação na música e, consequentemente na arte, indica elementos que estão na base da constituição da civilização e do contexto atual. "Para ser objecto de uma experiência total, toda a obra de arte exige o pensamento e, por conseguinte, a filosofia, a qual nada mais é do que o pensamento que não se deixa travar" (ADORNO, 2015, p. 395). Assim, estudar a produção musical e seus efeitos nos ouvintes é também possibilidade de entendimento da sociedade, produção de pensamento e, consequentemente, de combate à barbárie. 
Parece realmente cínico que, depois do que ocorreu na Europa e o que ainda ameaça ocorrer, dedique tempo e energia intelectual a decifrar os problemas esotéricos da moderna técnica da composição; além disso, as obstinadas discussões do texto, puramente formais, com frequência referem-se diretamente a uma realidade que não se interessa por elas. Mas talvez este começo excêntrico lance alguma luz sobre uma situação cujas conhecidas manifestações somente servem para mascará-la e cujo protesto só adquire voz quando a conivência oficial e pública assume uma simples atitude de não participação. Trata-se apenas de música (ADORNO, 2011, p.11).

Entendendo, então, que a regressão da audição e a estandardização da música são bárbaras, busca-se, neste trabalho, compreender esse processo para refletir sobre a sociedade atual. Perceber os elementos que compõem a lógica do consumo é fundamental para a compreensão do todo social, a começar pela arte.

Há mudanças históricas e sociais na constituição das sociedades que são expressas pelo tipo de arte que o grupo social produz. Até o período clássico, era considerada arte o que era agradável aos sentidos ou causava admiração, sendo elas restritas às classes dominantes. Na contemporaneidade, há dificuldades em se definir o que é arte, esses critérios clássicos já não são mais suficientes. Para Adorno (2015), a arte traz do período clássico a ideia de ser objetiva e mediatizada pela subjetividade. No entanto, ela não pode se reduzir à satisfação das pulsões:

Do clássico sobrevive a ideia das obras de arte como algo de objectivo, mediatizado pela subjetividade. De outro modo, a arte seria efectivamente um passatempo arbitrário qualquer, indiferente às outras atividades e, talvez, historicamente retrógrada. Reduzir-se-ia a produto de substituição de uma sociedade, cuja força não mais é consumida pela aquisição dos meios de subsistência e na qual é, contudo, limitada a satisfação das pulsões (ADORNO, 2015, p. 398).

Na lógica positivista do capitalismo, o conceito de arte se converte a serviço da indústria cultural, que se apropria dessa ideia para produzir entretenimento e vender. "O conceito de arte, a que o positivismo aspira, converge com o de indústria cultural; esta organiza efectivamente os seus produtos como sistema de estímulos, que a teoria subjectiva da projecção faz passar por arte" (ADORNO, 2015, p. 399). Os produtos da indústria cultural não são artísticos, mas se fazem passar por arte e assim são vendidos e consumidos. Sua função e seus objetivos não são aqueles da arte, mas do mercado e da circulação de mercadorias. Mesmo que não se possa desconsiderar que haja contradições nesse processo. 
Para compreender a arte em sua verdadeira expressão e não como mercadoria, é importante entender que a subjetividade é um componente importante da construção artística, pois o sujeito se reconhece na obra. No entanto, o indivíduo, na lógica capitalista, se coloca como consumidor da arte, transformando a arte em entretenimento. $\mathrm{Na}$ arte, aquele que a contempla promove sua autonegação, pois, para Adorno (2015, p. 401), "em confronto com qualquer belo, como Kant o constatou apenas no sublime, o sujeito torna-se consciente de sua nulidade e vai, além dela, até ao que é o outro". A arte é, portanto, possibilidade de encontro com o outro.

Segundo Adorno (2015), há uma relação importante estabelecida entre o conceito de belo como algo natural ou como uma construção histórica:

O conceito de belo natural toca numa ferida e pouco falta para que o confundam com a violência que a obra de arte, puro artefacto, impõe ao natural. Totalmente feita pelos homens, a obra de arte contrapõe-se pela sua aparência ao não fabricado, à natureza. Como puras antíteses, porém, referem-se uma à outra: a natureza à experiência de um mundo mediatizado, objectivado; a obra de arte à natureza, ao representante mediatizado da imediatidade. Por isso, a reflexão sobre o belo natural é inalienável na teoria da arte. Enquanto que, bastante paradoxalmente, as considerações sobre o belo natural, quase a temática em si, causam a impressão de serem antiquadas, monótonas, arcaicas (ADORNO, 2015, p.100-101).

Apesar de relacionado à natureza, Adorno $(2015$, p.401) afirma que "não existia, contudo, nenhuma beleza sem sujeito, que o belo se transforme num em-si só através de seu para-outro, é efeito da autoposição do sujeito". O belo é a possibilidade de encontro com o outro e de conhecimento da finitude humana. Ao reconhecer suas fraquezas, o sujeito se faz forte. A angústia humana é resultado da capacidade de se diferenciar, a ponto de não ser cego sobre si mesmo. De acordo com Adorno (2015, p. 401), "a melancolia da noite não é o estado de alma daquele que sente, mas ela só se apossa de quem se diferenciou tanto e de tal modo se tornou sujeito que a seu respeito não é cego". Assim, esse sujeito capaz de perceber sua própria melancolia se torna forte. "Só o sujeito forte e desabrochado, produto da dominação total da natureza e da sua injustiça, possui também a força de recuar perante o objecto e de revogar a sua autoposição. O sujeito do subjectivismo estético, porém, é fraco, outer-directed" (ADORNO, 2015, p. 401).

O belo e o feio não são assim definidos por uma razão em si próprios, mas também não se pode relativizá-los. “[...] assim como não há algo de simplesmente feio, assim como o feio se pode tornar belo mediante sua função, de igual modo não existe algo de simplesmente belo: é trivial afirmar 
que o mais belo pôr-do-sol, a mais bela rapariga, fielmente reproduzidos, se podem tornar horríveis" (ADORNO, 2015, p.411). Ao não se relativizá-los nem hipostasiá-los, belo e feio podem se tornar a negação um do outro. "A beleza é, em si, historicamente, o que se liberta na luta" (ADORNO, 2015, p. 411).

Ao se aproximar e distanciar da realidade, a arte acaba por tornar bela a liberdade, mesmo que, para Adorno (2015), uma liberdade possível. Assim, conforme o autor, "a arte realiza o protesto contra a realidade mediante a sua objectivação" (ADORNO, 2015, p. 420).

Segundo Marcuse (1977), a arte também é possibilidade de protesto contra a realidade. Ao entender a arte como um fazer humano que contesta o existente, o autor a define como possibilidade de transcendência. Marcuse defende as possibilidades de a arte transcender as relações sociais existentes, subvertendo a consciência dominante:

defendo que, em virtude da sua forma estética, a arte é absolutamente autônoma perante as relações sociais existentes. Na sua autonomia, a arte não só contesta estas relações como, ao mesmo tempo, as transcende, Deste modo, a arte subverte a consciência dominante, a experiência ordinária (MARCUSE, 1977, p. 11-12).

Mantendo essa posição de valorização qualitativa da estética, Marcuse (1977) salienta que, para a arte ser revolucionária, é preciso uma mudança radical no estilo e na técnica, que refletiria mudanças da própria sociedade e em suas relações, principalmente entre as classes sociais. Essa definição técnica da obra revolucionária não se refere à qualidade ou à autenticidade:

Para além disto, uma obra de arte pode denominar-se revolucionária se, em virtude da transformação estética, representar, no destino exemplar dos indivíduos, a predominante ausência de liberdade e as forças de rebelião, rompendo assim com a realidade social mistificada (e petrificada) e abrindo os horizontes da mudança (e libertação). Neste sentido, toda verdadeira obra de arte seria revolucionária, isto é, subversiva de percepção da realidade estabelecida, a aparição da imagem de libertação (MARCUSE, 1977, p. 13).

As condições históricas e sociais estão presentes na obra de arte, mas esta só se torna revolucionária, e, portanto, obra autêntica, se rompe com os pressupostos de dominação, seja por meio da técnica e do estilo, seja da própria estética. O elemento estético é, em si mesmo, portanto, fundamental para a transcendência e esta, para a mudança social. "A arte transcende a sua determinação social e se emancipa a partir do universo real do discurso e do comportamento, preservando, no entanto, a sua presença esmagadora" 
(MARCUSE, 1977, p. 19-20). A obra de arte tem sua própria lógica, que desafia a racionalidade das instituições dominantes. Ela transcende a realidade imediata ao permanecer atual por muitos séculos. "A obra de arte representa assim a realidade ao mesmo tempo em que a denuncia" (MARCUSE, 1977, p. 21). Ela rompe com a realidade atual, ao mesmo tempo em que a retrata, a denuncia dentro de outra lógica, que permitirá a fruição, não só pela técnica e pelo estilo, mas pela qualidade estética. Segundo Marcuse (1977), o conteúdo se torna forma.

Ao se abstrair da realidade, a arte comunica algumas verdades incomunicáveis em outros meios. Ao mostrar as contradições, sem deixar de lado a perspectiva estética, ela denuncia a realidade. "Neste sentido, a arte é arte pela arte na medida em que a forma estética revela dimensões da realidade interditas e reprimidas: aspecto da libertação" (MARCUSE, 1977, p.30).

Para Marcuse (1977), a arte faz parte do que existe e só por isso pode depor contra ele. Ela não busca a conciliação, mas a denúncia. $O$ objetivo da arte não pode ser o de conciliar a realidade, aplacando as tensões entre o universal e o particular, ou mesmo entre o sujeito e o objeto. "A arte é impotente contra esta reconciliação com o irreconciliável" (MARCUSE, 1977, p. 72).

Em uma sociedade alienada, como a capitalista, as possibilidades de liberdade e transcendência pela arte são diminuídas, quando não suprimidas. Assim, a arte se torna uma mercadoria reproduzida em larga escala para ser vendida e consumida, eliminando suas possibilidades de transcendência, pois o objetivo se torna outro: o mercado.

Essas transformações da arte em mercadoria, que passa a se tornar reproduzível em larga escala, ocorrem dentro do contexto da indústria cultural, em que:"divertir-se significa estar de acordo" (HORKHEIMER; ADORNO, 1985, p. 135). Nada pode surgir de novo, o que há é uma reformulação do que já está posto, o ar de semelhança deve sempre permear esses produtos. As músicas, assim como o cinema, seguem um padrão e se justificam a partir do lucro que geram:

O cinema e o rádio já não precisam mais se apresentar como arte. A verdade de que não passam de um negócio, eles a utilizam como ideologia destinada a legitimar o lixo que propositalmente produzem. Eles se definem a si mesmos como indústrias, e as cifras publicadas dos rendimentos de seus diretores gerais suprimem toda dúvida quanto à necessidade social de seus produtos (HORKHEIMER; ADORNO, 1985, p.114). 
Segundo Horkheimer e Adorno (1985), a indústria cultural, mesmo se assumindo como indústria do lucro, permanece a indústria da diversão. Ela se identifica com as necessidades produzidas, e a diversão se torna o prolongamento do trabalho. Ao tentar fugir do trabalho mecanizado, para conseguir novamente encará-lo, o sujeito busca o lazer, mas a indústria cultural também levou a lógica da dominação para esse aspecto da vida humana. Há uma sequência automatizada de repetições na diversão que segue a lógica do trabalho. O prazer que gera aborrecimento no lazer mecanizado não pode gerar esforços. "O espectador não deve ter necessidade de nenhum pensamento próprio, o produto prescreve toda reação" (HORKHEIMER; ADORNO, 1985, p.128).

O processo de divertimento, segundo Horkheimer e Adorno (1985), se dá pelo isolamento do processo social como um todo, no qual a capacidade da obra de refletir sobre esse todo é abandonada. O sofrimento, mesmo onde ele se torna evidente, precisa ser esquecido, pois a impotência está na própria base dessa lógica. Deve-se fugir não só aos aspectos ruins da realidade, "mas da última ideia de resistência que essa realidade ainda deixa subsistir" (HORKHEIMER; ADORNO, 1985, p.135).

Horkheimer e Adorno (1985) explicam que, por estar alheia ao processo de produção e da possibilidade de pensar e refletir sobre o que consome, a população passa da categoria de alienados da arte para consumidores compulsivos e irrefletidos desse entretenimento equivocadamente denominado de arte. A música estandardizada se insere justamente nesse processo de alienação e desumanização, se constituindo como bárbara. O processo de regressão da audição e de estandardização será discutido no próximo item.

2 - As (IM)POSSIBILIDADES DE TRANSCENDÊNCIA DA MÚSICA ESTANDARDIZADA: A REGRESSÃO DA AUDIÇÃO E A BARBÁRIE ESTÉTICA

Adorno e Simpson (1994) definem dois tipos de produção musical, denominadas por eles de séria e popular. Para os autores, a diferença está nos níveis, e ela se dá, fundamentalmente, quando se presta atenção numa característica que Adorno e Simpson (1994) atribuem à música popular, a estandardização. "Toda a estrutura da música popular é estandardizada, mesmo quando se busca desviar-se disso" (ADORNO; SIMPSON, 1994, p. 116).

Nesse sentido, música séria ou popular não se refere ao grupo ou indivíduo que a produz, mas às características de estandardização da produção, o que diferencia um tipo do outro. E, para eles, a estandardização 
deve ser observada a partir da própria produção da composição estrutural na relação entre as notas, o ritmo e a harmonia, pois a letra é poesia e cabe em outro tipo de análise, ligado à literatura.

A estandardização consiste em construir a música de acordo com um modelo ou uma forma estrutural definida previamente. Esse caráter de imposição e esses padrões são determinados pela indústria cultural. Segundo Adorno e Simpson (1994), o compositor não percebe, necessariamente, essa influência que lhe é imposta e pensa que é livre em sua composição. $\mathrm{O}$ esquema pré-digerido segue a lógica de mercado, atende a um determinado público consumidor em um contexto histórico, dissipando as possibilidades de transcendência e da produção de uma música séria, que poderia se caracterizar como artística. Ao contrário, a produção de um padrão garante que essa música possa ser vendida e não se preocupa com as características da arte.

Para Adorno e Simpson (1994), o objetivo da estandardização é obter o que eles chamam de audiência facilitada. Na música séria há também padronizações, mas que dizem respeito a uma técnica e priorizam a estética e não a sua transformação em mercadoria. Na música popular, a estandardização tem como objetivo prender os ouvintes desde as primeiras notas, pois, ao reconhecerem a semelhança, se identificam. $\mathrm{O}$ ar de semelhança que a indústria cultural promove nas mercadorias permite que o novo chegue sempre idêntico, sem contestar a realidade, servindo apenas para aumentar os lucros e incentivar o consumo.

"A estandardização se estende dos traços mais genéricos aos mais específicos" (ADORNO; SIMPSON, 1994, p. 116). A música não pode ter mudanças abruptas em sua composição, pois precisa ser conciliadora do início ao fim. "Complicações não têm consequências. Esse inexorável procedimento garante que, não importa que aberrações ocorram, o hit acabará conduzindo tudo de volta para a mesma experiência familiar, e que nada de fundamentalmente novo será introduzido" (ADORNO; SIMPSON, 1994, p. 116-117).

Os detalhes não são deixados de lado, mas neles há algo diferente da estrutura geral da música. Para eles, no detalhe, a estrutura é "escamoteada atrás de uma fachada de'efeitos' individuais, cujas prescrições são manipuladas por especialistas, por mais que este segredo esteja aberto aos músicos em geral" (ADORNO; SIMPSON, 1994, p.117). Por meio da tentativa de mostrar o detalhe que diferencia a música, mas que ao mesmo tempo a iguala, está o processo de indiferenciação do sujeito, que o desumaniza, recaindo em barbárie. 
O indivíduo se sente diferente ao se identificar com a música que ele considera como nova e a toma como sua, mas que, por ser um hit de sucesso, é escutada por todos e também meio de identificação para os outros, mas não de maneira profunda e reflexiva, e sim alienada.

A estandardização da estrutura musical busca reações estandardizadas do público. As pessoas perdem, nesse processo, a condição de sujeito. Os detalhes da música, assim como as pessoas na sociedade, podem ser previamente substituídos sem nenhum prejuízo à música, ao contrário do que ocorre no que Adorno e Simpson (1994) definem como música séria, pois," "na boa música séria, todo elemento musical, mesmo o mais simples'é ele mesmo'; e, quanto mais altamente organizada é a obra, menor é a possibilidade de substituição entre os detalhes" (ADORNO; SIMPSON, 1994, p.120).

O ouvido acostumado à música popular busca apenas o simples. Mesmo no que há de complexo, ele busca substituir por padrões estereotipados, o que não pode ocorrer na boa música séria, pois nela "cada detalhe deriva o seu sentido musical da totalidade concreta da peça, que, em troca, consiste na viva relação entre os detalhes, mas nunca na mera imposição de um esquema musical" (ADORNO; SIMPSON, 1994, p.117).

Na música popular, há uma conciliação entre o todo e as partes, a tensão é aplacada, pois, na indústria cultural, o divertimento é consentido sem que haja esforços reflexivos por parte do consumidor. Segundo Adorno e Simpson (1994), na música popular, é preciso que se entenda o mais simples evento sem esforço e esse esquematismo é garantido pela indústria cultural. Esse entendimento já está planejado e até mesmo organizado dentro da própria música. "A composição escuta pelo ouvinte. Esse é o modo de a música popular despojar o ouvinte de sua espontaneidade e promover reflexos condicionados" (ADORNO; SIMPSON, 1994, p.121).

Como mercadoria, a música se torna um fetiche. "De vez que os atrativos dos sentidos, da voz e do instrumento são fetichizados e destruídos de suas funções únicas que lhes poderiam conferir sentido" (ADORNO, 1983, p.172). Todos os elementos são padronizados, desde o tempo da música, que precisa ser igual em todas as composições, até a repetição de um refrão que precisa ser gravado pelos ouvintes.

Os consumidores, ao comprarem a música, também adquirem valores que não foram compreendidos nem apreendidos, segundo Adorno (1983). Em uma sociedade dominada pela mercadoria, a relação entre sujeito e objeto se inverte, com a coisificação dos sujeitos. "A liquidação do indivíduo constitui o sinal característico da nova época musical em que vivemos" (ADORNO, 1983, p.170). A eliminação das subjetividades é um ato de barbárie. A compreensão 
desse processo de alienação permite uma tentativa de resistência, que pode perpassar pela própria produção musical.

No entanto, o que ocorre é o contrário, e a música se torna uma mercadoria que o indivíduo pode comprar. Assim, ao poder comprá-la, ele se sente livre para fazer escolhas, mesmo que o que ele pode escolher está entre o que já foi predeterminado. Essa possibilidade que a indústria cultural oferece é o que propicia um aumento no consumo, pois, quanto mais "escolhas" o sujeito realiza, mais capital acumulado para as grandes produtoras.

Este processo de pseudoescolhas consiste no que Adorno e Simpson (1994) definem como pseudoindividuação. É preciso que se mantenha uma ilusão de individualidade. “O correspondente necessário da estandardização musical é a pseudo-individuação. Por pseudo-individuação entendemos o envolvimento da produção cultural de massa com a auréola da livre escolha ou do mercado aberto, na base da própria estandardização" (ADORNO; SIMPSON, 1994, p. 123). A estandardização os mantém presos a um esquema, e a pseudoindividuação faz com que eles esqueçam que esse esquema é préfabricado e sempre idêntico, mantendo a ilusão da novidade e da escolha livre.

É possível perceber, nesse processo de alienação da música, o quão violenta se faz a sua realização. A sociedade se torna cada vez mais bárbara, e o sujeito fica preso em um processo que reforça seu sofrimento. O esquema o mantém nessa condição por toda uma estrutura que se repete.

Para que uma música seja um novo hit de sucesso, e faça parte das escolhas dos sujeitos no consumo, ela é incorporada pelas agências de distribuição, sejam rádios, programas de TV, novelas e outros; e é incessantemente repetida, o que Adorno e Simpson (1994) definem como plugging. "O termo plugging tinha originalmente o estreito significado da repetição incessante de um hit particular, de modo a torná-lo um 'sucesso"' (ADORNO; SIMPSON, 1994, p.125). Eles explicam que utilizam esse termo em um sentido mais amplo, que estaria ligado também ao processo de composição, além da promoção e da divulgação do hit. E uma das funções do plugging é impossibilitar a fuga ao sempre idêntico. A repetição da música faz com que mesmo aquele que não havia se identificado inicialmente com o tema acabe por consumi-lo. O que ocorre aqui, segundo os autores, é a "institucionalização e a estandardização dos próprios hábitos de audição" (ADORNO; SIMPSON, 1994, p.125).

Os ouvintes se acostumam com a música e acabam por reagir de maneira automática ao hit. "A repetição confere ao hit uma importância psicológica que, de outro modo, ele jamais poderia ter. Essa promoção é o inevitável complemento da estandardização" (ADORNO; SIMPSON, 1994, 
p.125). Qualquer canção pode se tornar um sucesso, desde que preencha os requisitos mínimos; ela precisa se assemelhar a todas as demais, ao mesmo tempo em que se distingue delas, ao menos por uma característica: "A gravadora quer uma peça musical que seja fundamentalmente idêntica a todos os hits correntes e, ao mesmo tempo, fundamentalmente distinta deles" (ADORNO; SIMPSON, 1994, p.126).

Nessa lógica musical, há uma regressão da audição. “O que regrediu e permaneceu num estado infantil foi a audição moderna" (ADORNO, 1983, p. 180). Para o autor, os ouvintes não só perdem a liberdade de escolha, como negam a possibilidade do conhecimento. "Regressivo é, contudo, também o papel que desempenha a atual música de massas na psicologia de suas vítimas" (ADORNO, 1983, p.180). Como possibilidade de transcendência, a música propicia humanização; estandardizada e regredida, ela é barbárie.

Para Adorno e Simpson (1994), há bons motivos para supor que os ouvintes de música popular não a entendem como linguagem em si mesma, mas, ao escutá-la distraidamente, não fazem uma relação com o momento anterior e com o subsequente, o que explica a aceitação do material não diferenciado.

O que significa então a música para eles? A resposta é que a linguagem que a música é se transforma por processos objetivos em uma linguagem que eles pensam ser a deles, em uma linguagem que serve como um receptáculo para os seus desejos institucionalizados. Quanto menos a música é, para eles, uma linguagem sui generis, tanto mais ela se institucionaliza como receptáculo. A autonomia da música é substituída por uma simples função sociopsicológica. Em grande parte, a música é, hoje, um cimento social. E o significado que os ouvintes atribuem a um material, a lógica inerente a este, é inacessível a eles, está acima de todos os meios pelos quais eles alcançam algum ajustamento psíquico ao mecanismo da vida hodierna. Esse "ajustamento" materializa-se de dois modos diferentes, correspondendo aos dois tipos sociopsicológicos de comportamento de massa em relação à música em geral e à música popular em particular: o tipo "ritmicamente obediente" e o tipo "emocional" (ADORNO; SIMPSON, 1994, p.138).

Segundo Adorno e Simpson (1994), essa adesão dos ouvintes à música popular não é uma simples aceitação. O processo é mais complexo e se cobre de racionalizações que recaem em uma ambivalência. A busca por segurança se torna um masoquismo, pois, ao mesmo tempo em que sentem prazer, as pessoas sentem-se traidoras de si mesmas e em consequência traídas pela situação, ao renunciarem às possibilidades de transcendência. 
"A audição regressiva está a cada momento pronta para degenerar em furor" (ADORNO, 1983, p. 188).

Adorno e Simpson (1994) explicam que a mesma energia libidinal que o sujeito utiliza para se adaptar aos meios dominantes seria utilizada em uma possibilidade de transcendência e libertação:

A fim de se tornar um jitterbug ou simplesmente "gostar" de música popular, não basta, de modo algum, desistir de si mesmo e ficar passivamente alinhado. Para ser transformado em um inseto, o homem precisa daquela energia que eventualmente poderia efetuar a sua transformação em homem (ADORNO; SIMPSON, 1994, p.146).

Esse furor se volta contra o que eles consomem, mas rapidamente a indústria cultural se reorganiza para colocar à disposição novos objetos de consumo, com a promessa da completude. Ela esvazia e destitui de valores as relações humanas, colocando a possibilidade de felicidade, que nunca será alcançada, como possível em seus produtos:

O furor se dirige de imediato contra tudo aquilo que o modernismo da moda poderia desaprovar e mostrar quão reduzida foi a mudança que houve na realidade. [...] Eles gostariam de ridicularizar e destruir tudo aquilo que ainda ontem os encantava, como se quisessem vingar a posteriori deste falso encantamento. [...] Os ouvintes regressivos são realmente destrutivos (ADORNO, 1983, p.188).

Aparentemente, o indivíduo tem a opção de aceitar ou rejeitar uma canção, mas as agências de promoção, ao tocá-las exaustivamente e promoverem a nova música, retiram do ouvinte a possibilidade de rejeitá-la e ele acaba por consumi-la e se identificar com ela, mesmo quando não gosta ou não quer escutá-la. Essa energia gasta para "gostar" da música retorna posteriormente como um furor, assim que a próxima novidade é lançada. Uma importante característica desse furor é a ridicularização ao que não é novo, pois o novo só pode ser concebido, nessa lógica, como sempre idêntico aos anteriores e facilitado, para que o ouvinte não precise se esforçar. "A resistência é encarada como um sinal de má cidadania, como incapacidade de se divertir, como falta de sinceridade do pseudo-intelectual, pois qual a pessoa normal que poderia se colocar contra essa música normal?" (ADORNO; SIMPSON, 1994, p. 142).

Quanto mais despercebida ela se apresenta, ao mesmo tempo em que consegue promover a identificação, maior sucesso de vendas ela será. "A 'loucura' ou frenesi por uma determinada moda contém em si a latente possibilidade de fúria" (ADORNO; SIMPSON, 1994, p. 142). 
Os modismos tornam obsoleto o que há pouco tempo era consumido por todos. A música estandardizada mal resiste ao tema de uma novela ou um filme. A exaustão com que é ouvida no carro, em casa, no lazer e no trabalho, ao mesmo tempo em que promove uma maior adesão a ela, também aumenta esse furor que a ridiculariza pouco tempo depois que o hit esteve entre as paradas de sucesso. As mais vendidas se tornam rapidamente as mais ridicularizadas, e o ouvinte não suporta seu toque, sentindo-se irritado desde o início da música "ultrapassada". Não há composições perenes, e a possibilidade de transcendência se esvazia completamente, pois a música não deve ser apreciada, mas sim consumida.

Segundo Adorno e Simpson (1994), a pressão exercida por todos os lados para que o sujeito entre no esquema funciona como uma tortura de um prisioneiro político, que acaba confessando até mesmo crimes que não cometeu. $\mathrm{O}$ sujeito pressionado por todos os lados e a todos os momentos, pela indústria cultural, não vê possibilidade de escapar e, até certo ponto, acha normal o consumo desses produtos.

Há uma desproporção entre a força do indivíduo e a pressão social para ele aderir aos produtos preestabelecidos, que ele acredita de primeira necessidade. Essa insistência, que se assemelha a uma tortura, reitera o caráter bárbaro desse tipo de produção e distribuição do material musical:

Quando a música popular é repetida a ponto de não parecer mais um procedimento, mas antes um elemento inerente ao mundo natural, a resistência assume um aspecto diferente, porque a unidade da individualidade começa a se quebrar. É claro que isso não implica a absoluta eliminação da resistência. Mas ela é levada a estratos cada vez mais profundos da estrutura psicológica. A energia psicológica precisa ser investida diretamente, a fim de que se supere a resistência. Pois a resistência não desaparece completamente na rendição a forças externas, mas mantém-se viva dentro do indivíduo e continua sobrevivendo até mesmo no exato momento do consentimento. Aqui, o despeito torna-se drasticamente ativo (ADORNO; SIMPSON, 1994, p.143).

De acordo com Adorno e Simpson (1994), os sujeitos precisam negar essa dependência e se assumirem como livres. "Por isso, eles voltam o seu ódio antes contra aqueles que apontam sua dependência do que contra aqueles que apertam suas algemas" (ADORNO; SIMPSON, 1994, p.143). Os autores explicam que confessar que são alienados de suas escolhas é dizer que a individualidade desapareceu em relações estandardizadas no convívio social. Assim, "o rancor do engano é transferido para a ameaça de que ele se torne consciente e eles defendem com fervor a sua própria atitude, já que isso lhes permite serem voluntariamente enganados" (ADORNO; SIMPSON, 
1994, p.143). Para aderir a esse modo de vida não basta ser passivo, é preciso também de engajamento para forçar-se a aceitar, pois a ordem externa precisa ser internalizada e fazer parte da constituição desse sujeito:

O entusiasmo frenético implica ambivalência não só na medida em que está pronto a se converter em fúria real ou em humor sarcástico para com seus ídolos, mas também na efetivação dessa rancorosa decisão voluntária. O ego, ao forçar o entusiasmo, precisa hiper-forçá-lo, na medida em que o entusiasmo"natural" não bastaria para cumprir a tarefa e vencer a resistência (ADORNO; SIMPSON, 1994, p.144-145).

Este ouvinte se hiperforça a aceitar a música e se defende do furor contra si mesmo e seus ídolos por meio do humor. Segundo os autores, esse consumidor zomba de si mesmo e do material que ouve. E faz um tremendo esforço para liquidar com sua espontaneidade ao aceitar o que lhe é imposto.

Para Adorno e Simpson (1994), as possibilidades de mudanças nessa lógica da indústria cultural, em especial na música, são difíceis, mas cabe ao sujeito essa possibilidade. "As forças coletivas liquidam também na música a individualidade que já não tem chance de salvação. Todavia, somente os indivíduos são capazes de representar e defender, com conhecimento claro, o genuíno desejo de coletividade face a tais poderes" (ADORNO, 1983, p.191). Não há receitas fáceis ou simples, mas pensar o processo e analisá-lo pode indicar um começo.

\section{CONSIDERAÇÕES FINAIS}

Ao finalizar este trabalho, é preciso cuidado para não cair no erro de fechá-lo e conciliá-lo, buscando uma solução fácil para uma realidade em que diversos elementos se articulam.

Há uma pseudodemocratização das obras, que deixam de ser arte e se tornam, como entretenimento e mercadoria a serem consumidas, acessíveis aos que podem pagar por elas. Com a consolidação do modo de produção capitalista e o surgimento de uma lógica em que tudo pode ser consumido, por meio da promoção da indústria cultural, as obras se tornam sinal de status social e não mais são apreciadas, mas feitas para vender.

A preocupação dos artistas, neste contexto, não é mais com a produção de uma obra que tenha um sentido social de denúncia ou reflexão, por meio da exposição das contradições sociais, mas antes vise à aceitação pública e à venda de seu trabalho.

A arte, desde seu surgimento, que acompanha toda a história humana, contém em si a possibilidade de transcendência, exibindo um valor 
eterno, que resvala por séculos, mantendo-se atual em diferentes contextos, ao denunciar e expor as mazelas humanas. Nesta lógica atual, a arte se torna perene e atende apenas ao imediatismo de uma sociedade fetichizada, levando, inclusive, a ser possível afirmar que não se trata mais de arte.

A obra é substituída e perde o sentido assim que surge uma novidade, que mantém como característica principal não conter nada de novo, seguindo o esquematismo da estandardização, prevista pelas agências de controle.

A música moderna, que Adorno e Simpson (1994) definem como música popular, cuja principal característica é a estandardização, também segue esse padrão. Ao abrir mão da fruição profunda, que possibilita a transcendência, o sujeito se insere cada vez mais nesta lógica e os que tentam se desvencilhar dela são ridicularizados e excluídos.

Para Adorno e Simpson (1994), ao aceitar essa música, o sujeito não reage passivamente, antes precisa forçar-se a isso e gastar a energia que possibilitaria uma possível construção de autonomia.

Há um furor latente contra os hits de sucesso. Esse rancor é exposto logo que uma "novidade", que tem como característica a estandardização, é lançada. Essa novidade precisa seguir a padronização imposta pela indústria cultural, obedecida nos hits anteriores. Tudo o que foge a isso é excluído e desqualificado.

A possibilidade de transcendência pela música ou qualquer obra de arte só é possível se o próprio sujeito canalizar a energia, que, segundo Adorno e Simpson (1994), o indivíduo utiliza para aceitar os produtos pré-digeridos da indústria cultural, na produção desta arte verdadeira e em sua fruição, que Marcuse (1977) aponta como possibilidade de transcendência. Não se podem desconsiderar as contradições desse processo e pensar as possibilidades e impossibilidades da arte sem idealizá-la ou relativizá-la. 
REGRESSION OF HEARING AND BARBARISM: THE (IM)POSSIBILITIES OF STANDARDIZED MUSIC TRANSCENDENCE

ABSTRACT: Art is possibility of transcendence and humanization. To be removed from its reflective character and launched the logic of cultural industry, art becomes an element to be consumed and expression of barbarism, because the alienation prevents humanization. The regression of hearing in the music and its standardization are elements that lead to alienation, making it impossible to transcendence. This work comprises aspects of music today, that prevents the subject fully living the humanization and converts this art expression in barbarism. The analyzes in this article are based on a bibliographical research based on the concepts of the Critical Theory of the Frankfurt School.

KEYWORDS: Barbarism. Standardization.Music.Transcendence.

\section{LA REGRESIÓN DE LA AUDICIÓN Y LA BARBARIE: AS (IM) POSIBILIDADES DE TRANSCENDENCIA DE LA MÚSICA ESTANDARDIZADA}

RESUMEN: El arte es posibilidad de trascendencia y humanización. Al ser retirado de su carácter reflexivo y lanzado a la lógica de la industria cultural, el arte se convierte en un elemento a ser consumido y expresión de barbarie, pues la alienación impide la humanización. La regresión de la audición en la música y su estandarización son elementos que llevan a la alienación, imposibilitando la trascendencia. Este trabajo incluye aspectos de la música en la actualidad, que impiden que el sujeto viva plenamente la humanización y hacen de esa expresión de arte una barbarie. El análisis de este artículo se hace con base en una investigación bibliográfica fundamentada en los conceptos de la Teoría Crítica de la Escuela de Frankfurt.

PalABRAs claves: Barbarie. Estandarización. Música. Trascendencia.

\section{REFERÊNCIAS}

ADORNO, T. W. O fetichismo na música e a regressão da audição. In: Textos escolhidos. Walter Benjamin, M. Horkheimer, T. W. Adorno e J. Habermas. 2. ed. São Paulo, Abril Cultural, 1983. p. 165-191. (Os pensadores). . Educação e emancipação. São Paulo: Paz e Terra, 2006. . Filosofia da nova música. São Paulo: Perspectiva, 2011. . Teoria estética. Lisboa, Portugal: Edições 70, 2015. 
;: SIMPSON, G. Sobre música popular. In: COHN, G. (Org.). Theodor W. Adorno: grandes cientistas sociais. 2.ed. São Paulo: Editora Ática, 1994. p.115-146.

HORKHEIMER, M.; ADORNO, T. W. Dialética do esclarecimento. Rio de Janeiro: Jorge Zahar Editora, 1985.

MARCUSE, H. A dimensão estética. São Paulo: Martins Fontes, 1977.

Paola Regina Carloni: Doutora em Psicologia Escolar e do Desenvolvimento Humano (USP), mestre em Educação (UFG - 2010), graduada em Comunicação Social Jornalismo (2004) e Psicologia (2012) pela Universidade Federal de Goiás - UFG, especialista em Assessoria de Comunicação (UFG - 2008).

E-mail: paolacarloni@gmail.com 